\title{
ОЦЕНКА ВОССТАНОВИТЕЛЬНОЙ И ХЕЛАТИРУЮЩЕЙ СПОСОБНОСТИ ОРГАНИЧЕСКИХ ДИ- И ТРИСУЛЬФИДОВ
}

\author{
М.А. Половинкина', В.П. Осипова', А.Д. Осипова ${ }^{2}$, Н.Т. Берберова ${ }^{2}$ \\ ${ }^{1}$ Федеральный исследовательский центр ЮНЦ РАН, \\ 344006, Россия, г. Ростов-на-Дону, просп. Чехова, д.41. \\ ${ }^{2}$ Астраханский государственный технический университет, \\ 414056, Россия, г. Астрахань, ул. Татищева д.16.
}

DOI: 10.19163/MedChemRussia2021-2021-273

E-mail: polovinkina.ast@gmail.com

В работе методом FRAP (Ferric Reducing Antioxidant Power), основанным на способности антиоксидантов выступать в качестве доноров электрона, оценена восстанавливающая активность сераорганических соединений: дифенилтрисульфид (1), бис(2-метоксифенил)дисульфид (2), 4,4'-дигидроксифенилдисульфид (3), дифенилдисульфид (4), бис(3,5-ди-трет-бутил-4-гидроксифенил)дисульфид (5); дибутилдисульфид (6), ди-трет-бутилдисульфид (7), диаллилдисульфид (8), метилпропилтрисульфид (9). Антиоксидантный потенциал соединений 1-9 рассчитан в эквивалентах водорастворимого аналога витамина E - тролокса (TEAC FRAP $_{1}=1$ ). Методом, в основе которого заложено взаимодействие потенциальных антиоксидантов с ионами $\mathrm{Fe}^{2+}$, препятствующее образованию стабильного комплекса с феррозином, исследована $\mathrm{Fe}^{2+}$-хелатирующая активность ди-и трисульфидов. Для сравнения хелатирующей способности соединений 1-9 рассчитаны концентрации полумаксимального ингибирования (FIC, IC ${ }_{50}$, MM), представленные в таблице. Установлено, что ароматические олигосульфиды 1-5 не демонстрируют высокую активность в реакции восстановлении $\mathrm{Fe}^{3+}$ до $\mathrm{Fe}^{2+}$ по сравнению с тролоксом, а алифатические ди- и трисульфиды 6-9 вообще не проявляют восстановительной способности во FRAP-тесте.

\begin{tabular}{|c|c|c|c|c|c|c|c|c|c|}
\hline Соединение & 1 & 2 & 3 & 4 & 5 & 6 & 7 & 8 & 9 \\
\hline TEACFRAP & $\begin{array}{c}0.26 \pm \\
0.03\end{array}$ & $\begin{array}{c}0.58 \pm \\
0.02 \\
\end{array}$ & $\begin{array}{c}0.69 \pm \\
0.02\end{array}$ & $\begin{array}{c}0.06 \pm \\
0.05\end{array}$ & $\begin{array}{c}0.69 \pm \\
0.02\end{array}$ & $\mathrm{H} / \mathrm{a}$ & $\mathrm{H} / \mathrm{a}$ & $\mathrm{H} / \mathrm{a}$ & $\mathrm{H} / \mathrm{a}$ \\
\hline FIC, IC50 MM & $\begin{array}{c}7.76 \pm \\
1.1 \\
\end{array}$ & $\begin{array}{c}9.6 \pm \\
1.5 \\
\end{array}$ & $\begin{array}{c}5.62 \pm \\
0.9 \\
\end{array}$ & $\begin{array}{c}3.74 \pm \\
0.5 \\
\end{array}$ & $\begin{array}{c}8.69 \pm \\
0.8 \\
\end{array}$ & $\mathrm{H} / \mathrm{a}$ & $\mathrm{H} / \mathrm{a}$ & $\begin{array}{c}6.95 \pm \\
1.3 \\
\end{array}$ & $\begin{array}{c}0.19 \pm \\
0.1 \\
\end{array}$ \\
\hline
\end{tabular}

Большая активность характерна для соединений 2, 3 и 5, что объясняется наличием редокс-активных групп в бензольном кольце. Металлхелатирующую активность показывают все сераорганические соединения, кроме дисульфидов 6 и 7. Наибольшая хелатирующая активность обнаружена у метилпропилтрисульфида 9 $\left(\mathrm{IC}_{50}=0.19 \pm 0.01 \mathrm{MM}\right)$, остальные соединения имеют значительно меньшие значения концентраций полумаксимального ингибирования по сравнению с эталоном ЭДТА (IC ${ }_{50}=0.4 \pm 0.05$ мМ). Таким образом, изучена восстанавливающая и $\mathrm{Fe}^{2+}$ хелатирующая активности сераорганических соединений и не установлено выраженный зависимости проявления свойств от количества атомов серы (ди- и трисульфиды) и строения органического радикала (алифатический, ароматический).

Работа выполнена при поддержке гранта РНФ № 20-13-00084. 